\title{
EFFECTS OF BETA-HYDROXY-BETA-METHYL BUTYRATE IN MUSCLE REGENERATION OF RATS
}

\author{
EFEITOS DO BETA-HIDROXI-BETA-METIL-BUTIRATO NA REGENERAÇÃO MUSCULARDERATOS
}

EFECTOS DE BETA-HIDROXI-BETA-METILBUTIRATO EN LA REGENERACIÓN MUSCULAR DE RATAS

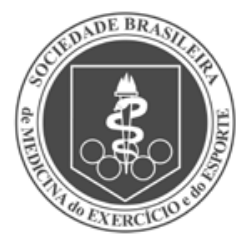

Original Article ARTIGo ORIGINAL Artículo Original
Larissa Antunes ${ }^{\uparrow}$

(Physiotherapyst Undergraduate)

André Katayama Yamada ${ }^{1}$

(Physical Education Professional)

Adriana Pertille 1

(Physiotherapyst)

1. Universidade Metodista de Piracicaba, Faculdade de Ciências da Saúde, São Paulo, SP, Brazil.

\section{Correspondence:}

Adriana Pertille. Rodovia do Açúcar, 7000, Bairro Taquaral, Piracicaba, São Paulo, SP, Brazil. 13400-911. apertille@unimep.br

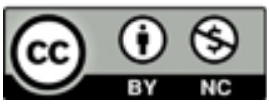

\begin{abstract}
Introduction: Studies have shown that beta-hydroxy-beta-methyl butyrate (HMB) supplementation increases muscle strength and mass. Objective: To evaluate the effect of HMB supplementation on the muscle regeneration process in young and sedentary rats. Methods: Twenty-four male Wistar rats two months old were divided into two groups: lesion (LE) and supplemented (S), and evaluated in two moments - seven days (LE7; S7, n=6) and 21 days (LE21; $S 21, n=6)$. The right tibialis anterior muscle was subjected to cryolesion in all animals. After the injury, the LE group remained in the vivarium without any intervention. Group $S$ received $\mathrm{HMB}$ calcium supplementation diluted in water by gavage $(320 \mathrm{mg} / \mathrm{kg} /$ weight per day). The injury tibialis anterior (ITA), the tibialis anterior (TA), and the left soleus (SOL) muscles were removed, weighted and divided transversally into two parts, one for the analysis of the cross-sectional area (CSA) and the area of inflammation/regeneration and the other part to measure the muscular glycogen concentration. Data were evaluated using the SAS program considering mean and standard deviation. For analysis of variance the ANOVA test was used followed by the Tukey-HSD test $(p \leq 0.05)$. Results: The ITA muscle weight was higher in S21 compared to S7 ( $p<0.05$ ). The groups LE21 and S21 presented greater CSA of muscle fibers area and smaller ITA regeneration/inflammation area $(p<0.05)$ when compared with the LE7 and S7 groups. There was an increase in muscle glycogen levels in S7 group compared to LE7 and S21 groups for TA and SOL $(p<0.01)$, as well as in S21 group compared to LE21 for SOL $(p<0.05)$. Conclusion: HMB did not influence the muscle regeneration process and did not favor anabolic activity in the different muscular fibers of young sedentary rats. Level of Evidence ll; Therapeutic studies - Investigation of treatment results.
\end{abstract}

Keywords: Metabolism; Leucine; Regeneration; Muscle, skeletal.

\section{RESUMO}

Introdução: Estudos demonstram que a suplementação de beta-hidroxi-beta-metil-butirato (HMB) aumenta a força e a massa muscular. Objetivo: Avaliar o efeito da suplementação com HMB no processo de regeneração muscular em ratos jovens e sedentários. Métodos: Foram utilizados 24 ratos Wistar machos com dois meses de idade, divididos nos grupos lesão (LE) e suplementado (S) e avaliados em dois momentos, em sete dias (LE7; $S 7, n=6)$ e em 21 dias (LE21; S21, n=6). O músculo tibial anterior direito foi submetido à criolesão em todos os animais. Após a lesão, o grupo LE permaneceu no biotério sem nenhum tipo de intervenção. O grupo S recebeu suplementação de cálcio HMB em pó diluído em água por meio de gavagem (320 mg/kg/peso por dia). Os músculos tibial anterior lesado (TAL), tibial anterior (TA) e sóleo (SOL) esquerdo foram retirados, pesados e divididos transversalmente em duas partes, sendo uma destinada à análise da área de corte transversal (ACT) e da área de inflamação/regeneração e a outra parte para medir a concentração de glicogênio muscular. A avaliação dos dados foi realizada por meio do programa SAS, considerando média e desvio padrão. Para análise de variância usou-se o teste ANOVA, seguido do teste de Tukey-HSD $(p \leq 0,05)$. Resultados: O peso do músculo TAL foi maior no $S 21$ em comparação com o $S 7(p<0,05)$. Os grupos LE21 e S21 apresentaram maior ACT de fibras musculares e menor área de regeneração/inflamação do TAL $(p<0,05)$, quando comparados com os grupos LE7 e S7. Observou-se aumento nos níveis de glicogênio muscular no grupo S7 com relação a LE7 e $S 21$ para TAE e SOL $(p<0,01)$, assim como no grupo $\$ 21$ em comparação com LE21 no SOL ( $p<$ 0,05). Conclusão: O HMB não influenciou o processo de regeneração muscular e não favoreceu a atividade anabólica nos diferentes tipos de fibras musculares de ratos jovens e sedentários. Nível de Evidência ll, Estudos terapêuticos Investigação dos resultados do tratamento.

Descritores: Metabolismo; Leucina; Regeneração; Músculo esquelético.

\section{RESUMEN}

Introducción: Los estudios han demostrado que el beta-hidroxi-beta-metilbutirato (HMB) suplementario aumenta la fuerza y la masa muscular. Objetivo: Evaluar el efecto del HMB suplementario en el proceso de regeneración muscular en ratas jóvenes y sedentarias. Métodos: Se utilizaron 24 ratas Wistar machos con dos meses de edad, divididas en los grupos lesión (LE) y suplementario (S) y evaluados en dos momentos, en siete días (LE7; $S 7, n=6$ ) y en 21 días (LE21; S21, $n=6$ ). El músculo tibial anterior derecho fue sometido a la criolesión en todos los animales. Después de la lesión, el grupo LE se mantuvo en el vivero sin ninguna intervención. El grupo S recibió calcio HMB suplementario diluido en agua por medio de alimentación forzada (320 mg/kg/peso al día). Los músculos tibial anterior 
lesión (TAL), tibial anterior (TA) y sóleo (SOL) izquierdo fueron retirados, pesados y divididos transversalmente en dos partes, siendo una destinada al análisis del área de corte transversal (ACT) y del área de inflamación/regeneración y otra parte para medir la concentración de glucógeno muscular. La evaluación de los datos se realizó a través del programa SAS, considerando media y desviación estándar. Para el análisis de varianza se utilizó la prueba ANOVA, seguida de la prueba de Tukey-HSD ( $p \leq 0,05)$. Resultados: El peso del músculo TAL fue mayor en el grupo $S 21$ en comparación con el S7 ( $p<0,05)$. Los grupos LE21 y $S 21$ tuvieron mayor ACT de fibras musculares y menor área de regeneración/inflamación del TAL $(p<0,05)$ en comparación con los grupos LE7 y S7. Se observó un aumento en los niveles de glucógeno muscular en el grupo $S 7$ con relación a LE7 y 521 para TA y SOL $(p<0,01)$, así como en el grupo S21 en comparación con LE21 en el SOL ( $p<0,05)$. Conclusión: HMB no influyó el proceso de regeneración muscular y no favoreció la actividad anabólica en los diferentes tipos de fibras musculares de ratas jóvenes y sedentarias. Nivel de Evidencia ll, Estudios terapéuticos - Investigación de los resultados del tratamiento.

Descriptores: Metabolismo; Leucina; Regeneración; Músculo esquelético.

\section{INTRODUCTION}

Several strategies are adopted to stimulate muscle regeneration, as the skeletal muscle is a tissue with appreciable regenerative potential, and one of these is nutritional supplementation. ${ }^{1-3}$

Beta-hydroxy-beta-methyl butyrate (HMB) is a metabolite of the amino acid leucine capable of stimulating muscle hypertrophy through increased synthesis and decreased protein degradation. ${ }^{4}$ Different studies have shown that HMB supplementation increases strength and muscle mass when associated with exercise. ${ }^{5-7}$ Holecek, $^{8}$ in a recent review, points out that the beneficial effects of $\mathrm{HMB}$ are well characterized in strength and resistance exercise. HMB can reduce the development of sarcopenia in the elderly and, when associated with exercise, favors muscle growth and increased strength. In muscle atrophy models, HMB supplementation exhibited a protective effect on skeletal muscle, diminishing the weakness and inflammation generated by this and other disorders, such as muscular dystrophy, acquired immune deficiency syndrome and corticosteroid therapy.,10

Kornasio et al. ${ }^{11}$ subjected cell cultures to apoptosis and noted that incubation of HMB in the myoblasts increased MyoD (cell proliferation marker) expression in a dose-dependent manner. The addition of various HMB concentrations in the culture for 24 hours resulted in a marked increase in MEF (Myocyte Enhancer Factor 2) and Myogenin (cell differentiation markers) expression. As an end result, it was noted in this experiment that there was an increase in the number of cells, as an indicator of proliferation and successful differentiation of myoblasts.

Another important cell mechanism for adult skeletal muscle regeneration is the proliferation and activation of satellite cells. Alway et al. ${ }^{12}$ demonstrated that HMB was able to promote satellite cell proliferation during muscle recovery after a period of disuse in senescent animals, and this observation illustrates the possible role of $\mathrm{HMB}$ in muscle regeneration.

To date, no study has assessed the effects of HMB on muscle regeneration in a live model. The regenerative capacity of skeletal muscle enables the healthy individual to achieve functional recovery of the injured segment within a matter of days after a trauma. In view of the above, it is suggested that HMB supplementation may favor muscle regeneration, since this metabolite has exhibited important anti-inflammatory, anti-apoptotic, hypertrophic, anti-atrophic, functional, and myogenic properties in skeletal muscle. Therefore, the aim of this study was to assess the effects of beta-hydroxy-beta-methyl butyrate (HMB) supplementation on the muscle regeneration process in young and sedentary animals.

\section{MATERIALS AND METHODS}

Twenty-four two-month-old adult male rats (mean body mass of $237.8 \pm 15.9 \mathrm{~g}$ ) were used. The animals were kept in the Vivarium of the
Faculdade Ciências da Saúde (School of Health Sciences) of Universidade Metodista de Piracicaba - UNIMEP under controlled ambient temperature, subjected to a 12-hour light-dark cycle, with feed and water ad libitum. Four animals were housed in each large polyethylene cage. The project was approved by the Institutional Review Board for Animal Experimentation of UNIMEP, under protocol No. 01/2015, and was conducted in accordance with the standards established in the Guide for the Care and Use of Laboratory Animals and in Ethical Principles in Animal Experimentation of Colégio Brasileiro de Experimentação Animal.

\section{Experimental groups}

The animals were randomly divided into four groups $(n=6)$ : Lesion seven days (LE7); Supplemented seven days (S7); Lesion 21 days (LE21) and Supplemented 21 days (S21).

All the animals were subjected to cryolesion in the right tibialis anterior muscle. The LE groups remained in the vivarium without intervention, while the $S$ groups received supplementation on a daily basis.

Body mass was checked after the first day of arrival of the animals at the vivarium, and repeated at each training session until the end of the experiment, using a calibrated digital scale (Filizola ${ }^{\circledR}$, Recife, Pernambuco, Brazil).

\section{Muscle Injury protocol}

The animals were anesthetized with an intraperitoneal injection of a mixture of ketamine hydrochloride $(1.16 \mathrm{~g} / 10 \mathrm{~mL})$ and xylazine hydrochloride $(2 \mathrm{~g} / 100 \mathrm{~mL})$, at a ratio of 3:2, at a dose of 0.09 and 0.06 $\mathrm{mL} / 100 \mathrm{~g}$ body weight, respectively. The right tibialis anterior muscle was exposed and injured with a $1 \mathrm{~cm}$ by $0.5 \mathrm{~cm}$ metal bar, cooled in liquid nitrogen for 30 seconds. The rod was pressed onto the muscle belly for 10 seconds, then immersed again in liquid nitrogen for 30 seconds, and pressed against the same part of the muscle for 10 seconds, according to the protocol of Miyabara et al..$^{13}$ The muscle fascia and skin were sutured and the animals were individually housed in boxes with feed and water until recovery. The left paw muscles were considered control.

\section{Treatment with beta-hydroxy-beta-methyl butyrate}

Beta-hydroxy-beta-methyl butyrate supplementation was administered by gavage daily for seven and 21 days, according to the experimental group, in the form of powdered calcium-HMB (Arnold Nutrition ${ }^{\circledR}$, Los Angeles, California, USA) at a dosage of $320 \mathrm{mg} / \mathrm{kg}$ of weight. ${ }^{14}$ The dose was mixed with distilled water $(170 \mathrm{mg} / \mathrm{mL})$. The sucrose present in the solutions was maintained so as to delay the gastric emptying process, which prevents a sudden increase in plasma HMB concentration and consequently its renal excretion. ${ }^{15}$ 


\section{Euthanasia of the animals}

At the end of the experimental period the animals were euthanized and the left and right tibialis anterior and left soleus muscles were removed, weighed and divided transversely into two equal parts, with one part set aside for the light microscopy technique and the other part for glycogen dosing.

\section{Histological analysis}

The muscles were frozen and sliced into $8 \mu \mathrm{m}$ cross sections using a cryostat (model HYRAX C 25 - Zeiss ${ }^{\circledR}$, Oberkochen, Germany) and stained with Hematoxylin and Eosin. The sections were used to analyze the location of the cell nucleus, the cross-sectional area (CSA) of the muscle fibers, and the quantification of the muscle inflammation/regeneration area (I/RA).

Two random sections per slide were used for the CSA analysis, with one slide for each animal. We counted 200 normal muscle fibers (control) and 200 regenerating fibers (centralized nucleus) using the Image Pro-Plus 6.2 (Media Cybernetics ${ }^{\circledR}$, Rockville, Maryland, USA) image analysis software, in 20x objective.

To evaluate the areas of inflammation and muscle regeneration, the slides were observed under a $4 \mathrm{X}$ objective optical microscope with coupled camera connected to a computer with Image Pro-Plus ${ }^{\circledR} 6.0$ software (Media Cybernetics ${ }^{\circledR}$, Rockville, Maryland, USA). After mounting the photo of the section of the right tibialis anterior muscle, we first measured the total area of the section then the area of muscle inflammation/regeneration, which is expressed as a percentage of the total area.

\section{Quantification of muscle glycogen}

To determine muscle glycogen, the samples were digested in heated $30 \% \mathrm{KOH}$ and the glycogen was precipitated using ethanol. The precipitated glycogen was subjected to acid hydrolysis in the presence of phenol according to the phenol-sulfuric acid method described by Lo, Russell and Taylor. ${ }^{16}$ Values were expressed in $\mathrm{mg} / 100 \mathrm{mg}$ of wet weight.

\section{Statistical analysis}

The data were evaluated using the SAS (Cary, North Carolina, USA) program, considering mean and standard deviation. After verifying the normality of the data, the one-way analysis of variance (ANOVA) test and Tukey's HSD post-hoc test were applied. A value of $\mathrm{p} \leq 0.05$ was adopted for statistical significance for all the analyses.

\section{RESULTS}

Mean body mass did not exhibit significant differences between the groups evaluated (Table 1).

Regarding the weight of the injured tibialis anterior muscle (ITA) there was a 20\% increase in weight in group S21 compared to S7 $(p<0.05)$. For the control tibialis anterior (TA) and soleus (SOL) muscles no statistical differences were observed between the groups (Table 1).

The CSA measurement of the TA and SOL muscle fibers showed no significant difference between the groups evaluated. The regenerating

Table 1. Mean and standard deviation of body mass and weight of the tibialis anterior and soleus muscles in grams of groups LE7 (7 days lesion); S7 (7 days supplemented); LE21 (21 days lesion) and S21 (21 days supplemented). BM: body mass; MW: muscle weight; ITA injured tibialis anterior; TA: control tibialis anterior; SOL: control soleus; $\mathrm{n}=6$.

\begin{tabular}{c|c|c|c|c}
\hline \multirow{2}{*}{ Group } & \multirow{2}{*}{ BM } & \multicolumn{3}{|c}{ MW } \\
\cline { 3 - 5 } \cline { 3 - 5 } & & ITA & TA & SOL \\
\hline LE7 & $280.83 \pm 20.5$ & $0.449 \pm 0.05$ & $0.490 \pm 0.05$ & $0.128 \pm 0.01$ \\
\hline S7 & $264.81 \pm 24.8$ & $0.406 \pm 0.07$ & $0.455 \pm 0.04$ & $0.120 \pm 0.02$ \\
\hline LE21 & $298.06 \pm 18.0$ & $0.506 \pm 0.04$ & $0.548 \pm 0.06$ & $0.134 \pm 0.20$ \\
\hline S21 & $288.12 \pm 27.2$ & $0.508 \pm 0.07^{*}$ & $0.534 \pm 0.05$ & $0.121 \pm 0.02$ \\
\hline
\end{tabular}

*differs from group $\mathrm{S7} ; \mathrm{p}<0.05$ fibers had a significant difference between the LE7 and LE21 groups ( $p<0.05)$, and between the S7 and 521 groups ( $p<0.05$ ), yet no difference was observed between the injured and supplemented groups. (Figure 1)

In the histological sections of the ITA muscle in the seven-day groups we observed intense inflammatory infiltrate and fibers in initial regeneration process. (Figure $2 \mathrm{~A}$ and $\mathrm{B}$ ). Absence of inflammation and the visualization of regenerated muscle fibers (with centralized nucleus) were noted 21 days after the injury in both groups evaluated (Figure $2 \mathrm{C}$ and D). In the control groups we observed fibers with a peripheral nucleus, polygonal shape and without inflammatory infiltrate in the TA and SOL muscles in all groups.

The quantification of the percentage of the area of inflammation and regeneration of the ITA muscle showed a reduction in inflammation in the 21 days groups when compared to the respective seven days groups $(p<0.05)$. The groups supplemented with HMB exhibited no statistical difference when compared to the non-supplemented groups. (Figure 3)

Regarding the quantification of glycogen for the TA muscle, group S7 presented an increase in comparison to groups LE7 ( 29\%) and S21 ( 27\%) ( $p<0.01$, Table 1). No significant differences were observed

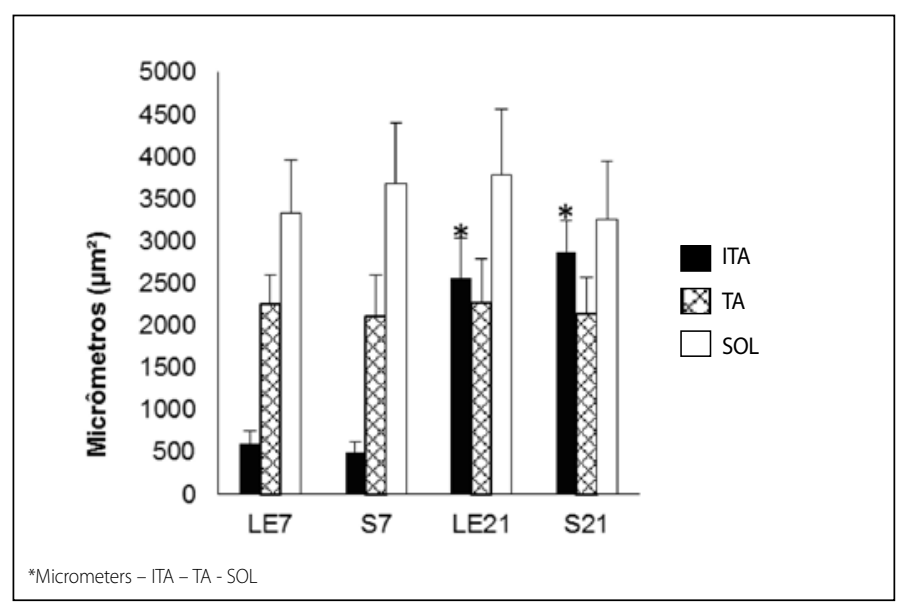

Figure 1. Mean and standard deviation of the cross-sectional area of muscle fiber in $\mu \mathrm{m} 2$ of the tibialis anterior (injured and control) and soleus muscles of groups LE7 (7 days lesion), S7 (7 days supplemented); LE21 (21 days lesion) and S21 (21 days supplemented). ITA: injured tibialis anterior; TA: control tibialis anterior; SOL: control soleus. $\left.n=6 .{ }^{*}\right)$ differs from the respective 7 days group; $(p<0.05)$.

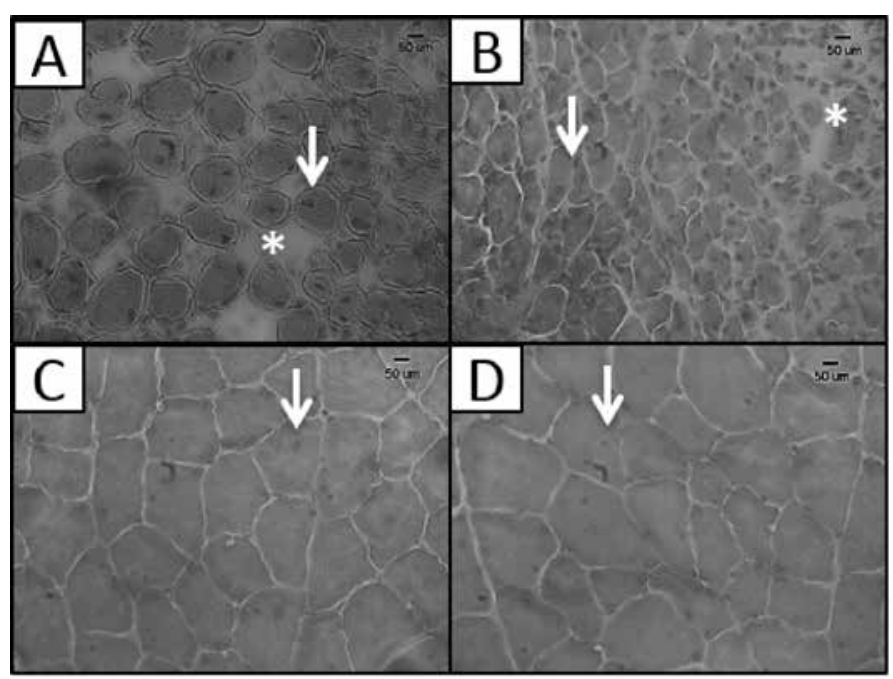

Figure 2. Cross sections of the injured tibialis anterior muscle, In A: group LE7 and B: group S7, note the area of inflammation $\left(^{*}\right)$ and fibers in initial regeneration process 7 days after lesion, with centralized nucleus (arrow). In C: group LE21 and D: group S21, note fibers in advanced process of regeneration 21 days after lesion, with centralized

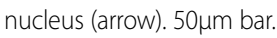


between the 21 days groups (LE21 and S21), or between the injured groups (LE7 and LE21). In the SOL muscle, no significant difference was observed for the injured groups (LE7 and LE21). Group S21 had reduced muscle glycogen $(\sim 25 \%)$ in comparison to $S 7$ ( $p<0.01$ ), yet showed an increase ( 37\%) in comparison to LE21 ( $p<0.05)$. Group S7 showed an increase ( 44\%) in comparison to LE7. (Figure 4, $p<0.05$ )

\section{DISCUSSION}

This study demonstrated that HMB supplementation did not favor muscle regeneration and did not have any effect on CSA increase, reduction of inflammation and maximization of muscle regeneration of young and sedentary rats subjected to cryolesion. The results demonstrated that the supplementation protocol used did not influence the body mass of the animals or the CSA of the control groups. However, there was an increase in muscle glycogen in the initial phase of supplementation in the two muscles evaluated.

$\mathrm{HMB}$ is a metabolite derived from the essential amino acid Leucine, which is endogenously converted into HMB in small amounts of about $5 \%$. It has been shown to have an anticatabolic effect both in humans and in animals, and may lessen the degradation of muscle proteins, acting as a protector against muscle damage and stimulating myogenic cell differentiation..$^{14,17}$ However, there are also studies that did not find any

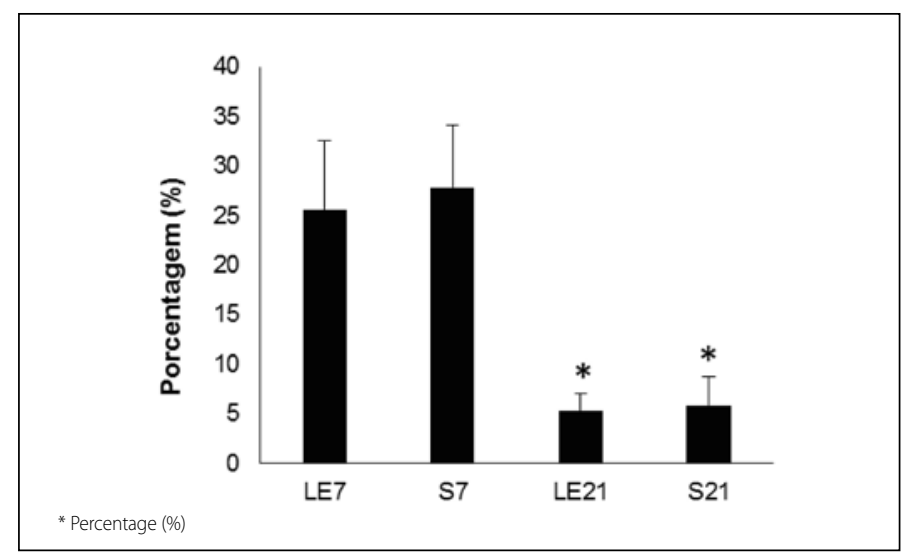

Figure 3. Mean and standard deviation of percentage of area of inflammation and regeneration of the tibialis anterior muscle lesion in groups LE7 (7 days lesion), S7 (7 days supplemented); LE21 (21 days lesion) and S21 (21 days supplemented). I/RA: inflammation/regeneration area; ITA: injured tibialis anterior. $\mathrm{N}=6$. $\left(^{*}\right)$ differs from the respective 7 days group; $(p<0.05)$.

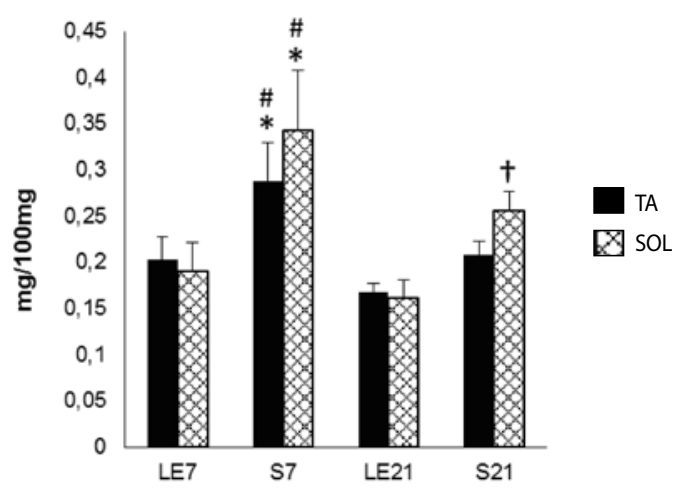

Figure 4. Mean and standard deviation of the amount of glycogen in mg/100mg, in the control tibialis anterior and control soleus muscles in groups LE7 (7 days lesion), S7 (7 days supplemented); LE21 (21 days lesion) and S21 (21 days supplemented). GL: glycogen; TA: control tibialis anterior; SOL: control soleus. $n=6 .\left(^{*}\right)$ differs from LE7; (\#) differs from S21 ( $<<0.01)$; $(\dagger)$ differs from LE21 ( $p<0.05)$. benefits of HMB supplementation in the skeletal muscle of healthy yet sedentary individuals ${ }^{18}$ or animals, ${ }^{19,20}$ as observed in this study.

Yonamine et al..$^{20}$ observed loss of insulin sensitivity of the soleus muscle of healthy sedentary rats supplemented with HMB (320 mg/ $\mathrm{kg}$ ) for four weeks, indicating that, in the long term, supplementation not associated with exercise may lead to a higher risk of developing type 2 diabetes.

The study by Hao et al. ${ }^{14}$ tested the hypothesis that HMB could reduce myonuclear apoptosis in the plantar and soleus muscles of elderly rats in response to disuse (immobilization via hind limb suspension) for 14 days, followed by reuse. In one of the groups analyzed, supplementation started the week before suspension, totaling 21 days. The results showed that HMB did not interfere in the body mass of the animals compared to the control group, nor was it able to prevent the reduction of CSA resulting from suspension in the soleus and plantar muscles. The same result was observed in this study, where body mass and CSA of the muscles evaluated were similar for the supplemented animals and controls, in both the injured and uninjured groups.

The groups supplemented for seven days did not show any improvement in the area of inflammation or in CSA when compared to the group without supplementation, which corroborates the findings of Baptista et al., ${ }^{17}$ who suggest that seven days of supplementation are not sufficient to restore muscle function or confer CSA protection in atrophy situations.

Regarding the increase in the weight of the tibialis anterior muscle 21 days after injury, studies suggest that the maximum peak of the effect of HMB starts in the second week of supplementation, 14,21 yet the increase in muscle weight did not reflect on the increase in CSA of the muscle fibers in the groups evaluated.

Wilson et al. ${ }^{22}$ cite in their review that HMB should accelerate the skeletal muscle regeneration process when followed by prolonged or high intensity physical activity. However, their results were contradictory, as they showed that there are several protocols suggested with the use of $\mathrm{HMB}$, as well as its combination with other substances in different experimental models.

The study by Girón et al. ${ }^{21}$ demonstrated that HMB supplementation for 28 days was able to protect the CSA of the gastrocnemius and soleus muscles in a dexamethasone-induced atrophy model of young rats, considering that the supplementation started in the week prior to the atrophy protocol. In addition, according to other authors, the effects of HMB proved effective in a 28-30 day protocol, with one prior week of supplementation, when immobilization procedures were performed along with corticosteroid administration. ${ }^{21,23,24}$

A study conducted with young rats supplemented with $\mathrm{HMB}$ at the same dosage as in this study, but for 28 days, showed a four-fold increase in muscle glycogen compared to the placebo group in the white portions of the gastrocnemius muscle, and a five-fold increase in the red portion. ${ }^{24}$ Our results showed that the group supplemented for seven days obtained a higher glycogen dosage than the seven days injured and 21 days supplemented for TA and SOL, while SOL glycogen was higher in the group supplemented for 21 days compared to the group injured 21 days previously.

Pereira et al. ${ }^{25}$ demonstrated that supplementation with leucine (a precursor of $\mathrm{HMB}$ ) increased the size of the soleus myofiber 10 days after cryolesion, by lessening protein ubiquitination, indicating that muscle mass regeneration is independent of protein synthesis modulation. It is important to emphasize that the authors supplemented the rats prior to cryolesion for three days.

The possible explanation of our results in view of the 21 days of lesion and supplementation can be divided into three different options, 
according to information obtained by the aforementioned studies: HMB did not have an effect, as the animals remained sedentary, since HMB has the effect of increasing muscle regeneration capacity associated with high intensity or prolonged exercise ${ }_{1}^{8,22}$ the 21 -day period was insufficient, since studies indicate that 30 days $^{23}$ or 28 days of supplementation ${ }^{21}$ demonstrated protective effects on muscle mass and CSA, suggesting that prolonged treatment could influence the results; in this study, supplementation started on the same day as the muscle injury, unlike the study by Girón et al. ${ }^{21}$ and Pereira et al., ${ }^{25}$ suggesting that initiating HMB supplementation prior to injury could alter muscle response.

It is worth mentioning that cryolesion is a lesion model that generates extensive inflammatory process in the acute phase, ${ }_{1}^{25}$ and there are few studies relating the use of $\mathrm{HMB}$ in muscle regeneration by cryolesion. Further studies are needed to better evaluate the effects of HMB on muscle regeneration and its behavior in the sedentary animal.

\section{CONCLUSIONS}

$\mathrm{HMB}$ did not exhibit efficacy in muscle regeneration considering the protocol used. In addition, supplementation did not favor the increase of the cross-sectional area or glycogen in the soleus and tibialis anterior muscles of young and sedentary rats.

All authors declare no potential conflict of interest related to this article.

AUTHORS' CONTRIBUTIONS: Each author made significant individual contributions to this manuscript. LA (0000-0003-3393-649X)*, AKY (0000-0002-2894-5407)* and AP (0000-0002-6979-342X)*: were the main contributors in the drafting of the manuscript; LA (0000-0003-3393-649X)* and AKY (0000-0002-2894-5407)*: performed the supplementation, the cryolesion and the collection of material and analyzed the histology slides; LA (0000-0003-3393-649X)* and AP (0000-0002-6979-342X)*: evaluated the data from the statistical analysis. LA, AKY and AP performed the bibliographic search, reviewed the manuscript and contributed to the intellectual concept of the study. ${ }^{*}$ ORCID (Open Researcher and Contributor ID).

\section{REFERENCES}

1. Shreeram S, Ramesh S, Puthan JK, Balakrishnan G, Subramanian R, Reddy MT, et al. Age associated decline in the conversion of leucine to $\beta$-hydroxy- $\beta$-methylbutyrate in rats. Exp Gerontol. 2016;80:6-11.

2. Tipton, KD. Nutrition for acute exercise-induced injuries. Ann Nutr Metab. 2010;57(Suppl 2):43-53.

3. Thomson RL, Buckley JD. Protein hydrolysates and tissue repair. Nutr Res Rev. 2011;24(2):191-7.

4. Durkalec-Michalski K, Jeszka J. The efficacy of a $\beta$-hydroxy- $\beta$-methylbutyrate supplementation on physical capacity, body composition and biochemical markers in elite rowers: a randomised, double-blind, placebo-controlled crossover study. J Int Soc Sports Nutr. 2015;12:31.

5. Park BS, Henning PC, Grant SC, Lee WJ, Lee SR, Arjmandi BH, et al. HMB attenuates muscle loss during sustained energy deficit induced by calorie restriction and endurance exercise. Metabolism. 2013;62(12):1718-29.

6. Albert FJ, Morente-Sánchez J, Ortega FB, Castillo MJ, Gutiérrez Á. Usefulness of $\beta$-hydroxy- $\beta$ methylbutyrate (HMB) supplementation in different sports: an update and practical implications. Nutr Hosp. 2015;32(1):20-33.

7. Berton L, Bano G, Carraro S, Veronese N, Pizzato S, Bolzetta F, et al. Effect of oral beta-hydroxy-beta-methylbutyrate (HMB) supplementation on physical performance in healthy old women over 65 years: an open label randomized controlled trial. PLoS One. 2015;10(11):e0141757.

8. Holeček M. Beta-hydroxy-beta-methylbutyrate supplementation and skeletal muscle in healthy and muscle-wasting conditions. J Cachexia Sarcopenia Muscle. 2017;8(4):529-41.

9. Kimura K, Cheng XW, Inoue A, Hu L, Koike T, Kuzuya M. $\beta$-Hydroxy- $\beta$-methylbutyrate facilitates $\mathrm{PI} 3 \mathrm{~K} / \mathrm{Akt}$-dependent mammalian target of rapamycin and FoxO1/3a phosphorylations and alleviates tumor necrosis factor a/interferon $\gamma$-induced MuRF-1 expression in $\mathrm{C} 2 \mathrm{C} 12$ cells. Nutr Res. 2014;34(4):368-74.

10. Aversa Z, Alamdari N, Castillero E, Muscaritoli M, Rossi-Fanelli F, Hasselgren PO. $\beta$-Hydroxy- $\beta$ methylbutyrate (HMB) prevents dexamethasone-induced myotube atrophy. Biochem Biophys Res Commun. 2012;423(4):739-43

11. Kornasio R, Riederer I, Butler-Brown G, Mouly V, Uni Z, Halevy O. Beta-hydroxy-beta-methylbutirate (HMB) stimulates myogenic cell proliferation, differentiation and survival via the MAPK/ERK and PI3K / Akt pathways. Biochim Biophys Acta. 2009;1793(5):755-63.

12. Alway SE, Pereira SL, Edens NK, Hao Y, Bennett BT. B-Hydroxy- $\beta$-methylbutyrate (HMB) enhances the proliferation of satellite cells in fast muscles of aged rats during recovery from disuse atrophy. Exp Gerontol. 2013; 48(9):973-84.

13. Miyabara EH, Martin JL, Griffin TM, Moriscot AS, Mestril R. Overexpression of inducible 70 kDa heat shock protein in mouse attenuates skeletal muscle damage induced by cryolesioning. Am J Physio Cell Physiol. 2006;290(4): C1128-38

14. Hao Y, Jackson JR, Wang Y, Edens N, Pereira SL, Always SE. $\beta$-Hydroxy- $\beta$-methylbutyrate reduces myonuclea apoptosis during recovery from hind-limb suspension-induced muscle fiber atrophy in aged rats. Am J Physiol Regul Integr Comp Physiol. 2011;301(3):R701-15.

15. Vukovich MD, Stubbs NB, Bohlken RM. Body composition in 70-year-old adults responds to dietary $\beta$-Hydroxy- $\beta$-Methylbutyrate similarly to that of young adults. J Nutr. 2001;131(7):2049-52.

16. Lo S, Russell JC, Taylor AW. Determination of glycogen in small tissue samples. J Appl Physiol. 1970;28(2):234-6

17. Baptista IL, Silva WJ, Artioli GG, Guilherme JP, Leal ML, Aoki MS, et al. Leucine and HMB differentially modulate proteasome system in skeletal muscle under different sarcopenic conditions. PLoS One. 2013; 8(10):e76752.

18. Nissen SL, Abumrad NN. Nutritional role of the leucine metabolite $\beta$-hydroxy- $\beta$-methylbutyrate (HMB) J Nutr Biochem.1997;8(6):300-11.

19. Kovarik M, Muthny T, Sispera L, Holecek M. Effects of $\beta$-hydroxy- $\beta$-methylbutyrate treatment in different types of skeletal muscle of intact and septic rats. J Physiol Biochem. 2010;66(4):311-19.

20. Yonamine CY, Teixeira SS, Campello RS, Gerlinger-Romero F, Rodrigues CF Jr, Guimarães-Ferreira L, et al. Beta hydroxy beta methylbutyrate supplementation impairs peripheral insulin sensitivity in healthy sedentary Wistar rats. Acta Physiol (Oxf) 2014;212(1):62-74.

21. Girón MD, Vílchez JD, Shreeram S, Salto R, Manzano M, Cabrera E, et al. $\beta$-Hydroxy- $\beta$-Methylbutyrate (HMB) Normalizes Dexamethasone-Induced Autophagy-Lysosomal Pathway in Skeletal Muscle. PloS One. 2015;10(2): e0117520.

22. Wilson JM, Fitschen PJ, Campbell B, Wilson GJ, Zanchi N, Taylor L, et al. International society of sports nutrition position stand: beta-hydroxy-beta-methylbutyrate (HMB). J Int Soc Sports Nutr. 2013;10(1):6.

23. Pinheiro CH, Gerlinger-Romero F, Guimarães-Ferreira L, de Souza Jr AL, Vitzel KF, Nachbar RT, et al. Metabolic and functional effects of beta-hydroxy-beta-methylbutyrate (HMB) supplementation in skeletal muscle. Eur J Appl Physiol. 2012;112(7):2531-7.

24. Pimentel GD, Rosa JC, Lira FS, Zanchi NE, Ropelle ER, Oyama LM, et al. $\beta$-Hydroxy- $\beta$-methylbutyrate $(H M B)$ supplementation stimulates skeletal muscle hypertrophy in rats via the mTOR pathway. Nutr Metab. 2011;8(1):11.

25. Pereira MG, Baptista IL, Carlassara EO, Moriscot AS, Aoki MS, Miyabara EH. Leucine supplementation improves skeletal muscle regeneration after cryolesion in rats. PLoS One. 2014;9(1):e85283. 